\title{
Tax Agents' Acceptance of the Digitalisation of Tax Administration in Malaysia
}

\author{
Suzana Che Saruji ${ }^{1}$, Nadiah Abd Hamid ${ }^{2}$ \\ \{wana.suzana@gmail.com ${ }^{1}$, nadiahhamid71@gmail.com $\left.{ }^{2}\right\}$ \\ Faculty of Accountancy, Universiti Teknologi MARA, Malaysia ${ }^{1,2}$
}

\begin{abstract}
Digitalisation has changed the way we navigate the economy with the transition to Industry 4.0. The government and taxpayers should work together with tax agents to engage in digital transformation. Moreover, the Government provides a range of incentives in Budget 2020 to accelerate economic growth in the New Economy and Digital Age and further promote high-value - added activities in the digital $5 \mathrm{G}$ economy and Industry 4.0. This study seeks to explore factors that influence tax agents' readiness in embracing the digitalisation of tax administration. The results are vital to the policymakers to enhance digital transformation that will improve efficiency and effectiveness of the tax administration. Digitalisation also act as important insights for tax practitioners and future researchers researchers to study the improvement factors of the tax administration system. As a result, tax compliance will increase tax collection and the recovery of income will further be enhanced.
\end{abstract}

Keywords: Tax Agents, Readiness, Acceptance, Industry 4.0, Digitalisation, Tax Administration, Technology Acceptance Model.

\section{Introduction}

Nowadays, issues such as regulatory changes and globalization deliver numerous challenges in complying with tax rules and regulations. For business owners, they must overcome difficulties in assessing their tax and financial data, especially when it is spread out among multiple enterprise resource planning (ERP) systems and tax processes may not support new submission requirements. Digitalisation has the potential to transform the world economy much more than what we see today because it affects not just how we produce and consume, but the kind of goods and services required [1]. Modern digital technology is used to digitalise analogue materials in order to transmit the data to the users [2] which, in this context are the tax agents.

For tax administration, digitalisation represents both challenges and opportunities, which go beyond the simple changing of a communication channel with tax administrators or the transformation of existing services from paper to digital [3]. By using modern technology, time-consuming operations may become instantaneous. As people are constantly online and linked, they now expect tax payments to be part of their digital environment. Many taxpayers have to rely on tax agents to fulfil the compliance with tax obligations [4]. As such, this study aims to examine the readiness of tax agents to tackle the challenges and opportunities, including the acceptance of the digitalisation of tax administration in Malaysia. 
To tax agents, technology intervention will have an impact on their roles in the taxation system. Plainly, digital technology will ensure tax returns are pre-populated by automatically exporting data from accounting software [5]. So, tax agents must familiarise themselves with the new technology used in the taxation system. Digital technologies give allow tax systems to compare information from different counterparts in real (near) time to which would enables rapid verification of transactions, minimization of errors and protection against fraud.

Institute of Chartered Accountants in England and Wales (ICAEW) recommends that each country should take into account the existing and expected functions of tax agents as part of the tax ecosystem. This recommendation would ensure more advantages and functionality to promote the work of tax authorities as well as tax agents [6]. Tax authorities from many countries realize that digitalisation will make them stronger, faster and better. Digital tools allow tax administrations to be more coordinated and effective in both combating corruption and in improving the quality of tax reporting and tax collection [3].

The electronic profiles of national tax administrations can be divided into five groups, which are e-filing, e-accounting, e-match, e-audit and e-assess. As of the year 2016, the global digitalisation level marked by a few countries is shown in Table 1.1. (Ernst and Young, 2017).

Table 1. Level of Digitalisation of Tax Administration Sources: (Ernst and Young, 2017)

\begin{tabular}{|c|c|c|c|c|}
\hline 1. E-file & 2. E-accounting & 3. E-match & 4. E-audit & 5. E-access \\
\hline $\begin{array}{l}\text { Use of uniform } \\
\text { electronic form } \\
\text { to file required } \\
\text { and optional tax } \\
\text { returns; all } \\
\text { income } \\
\text { information (e.g., } \\
\text { payroll and } \\
\text { financial) are } \\
\text { filed } \\
\text { electronically } \\
\text { and matched } \\
\text { annually. }\end{array}$ & $\begin{array}{l}\text { Submit } \\
\text { accounting or } \\
\text { other data source } \\
\text { in a specified } \\
\text { electronic format } \\
\text { to support } \\
\text { submissions (e.g. } \\
\text { invoices and court } \\
\text { balances) in a } \\
\text { specific timeline; } \\
\text { regular updates } \\
\text { and changes at } \\
\text { this stage. }\end{array}$ & $\begin{array}{l}\text { Submit } \\
\text { additional } \\
\text { accounting and } \\
\text { original } \\
\text { information; the } \\
\text { government } \\
\text { accesses } \\
\text { additional data } \\
\text { (bank } \\
\text { statements) and } \\
\text { starts to match } \\
\text { data in real-time } \\
\text { across tax forms, } \\
\text { and likely across } \\
\text { taxpayers and } \\
\text { jurisdictions. }\end{array}$ & $\begin{array}{l}\text { Level-2 data } \\
\text { analysed by } \\
\text { government } \\
\text { agencies and } \\
\text { cross-checked to } \\
\text { filings in real- } \\
\text { time to map the } \\
\text { geographic } \\
\text { economic } \\
\text { ecosystem; } \\
\text { taxpayers } \\
\text { receiving } \\
\text { electronic audit } \\
\text { assessments with } \\
\text { the limited } \\
\text { response time. }\end{array}$ & $\begin{array}{l}\text { Government } \\
\text { entities used } \\
\text { information } \\
\text { submitted to } \\
\text { measure tax } \\
\text { without the } \\
\text { need for tax } \\
\text { forms; } \\
\text { taxpayers } \\
\text { given a limited } \\
\text { amount of time } \\
\text { to review and } \\
\text { respond to the } \\
\text { tax determined } \\
\text { by the } \\
\text { government. }\end{array}$ \\
\hline
\end{tabular}

Tax agents will have fewer tasks to do under digitalisation as they would spend less time collecting, reviewing, and organizing data from clients. Since information comes from business systems and government records, it possible input errors from manual entry can be eliminated [7]. Nonetheless, like in other industries where innovation has increased, the likely effect is the role of tax agents would rise up the value chain, away from enforcement work and advisory work. Digitalisation will only have an adverse impact on tax professionals if they donot innovate and transfer their work to emerging areas. Tax professionals will be more focused on auditing pre-filled returns and assisting data suppliers with their increased reporting burden. The types of tax advice they provide will also expand, with higher demand 
for compliance work as well as helping clients transition their business models due to the increasingly changes in digital economy [8]. Deloitte [9] indicated that, in order to successfully navigate current challenges and make the best use of opportunities for growth and the scope offered by digitalisation, tax agents need to orient themselves and drive forward transformation as the challenges are ongoing and impact their scope of work related to tax administration.

\section{Literature review}

\subsection{Readiness to accept of the Digitalisation in Tax Administration}

Tax and transformation services will be delivered to taxpayers by tax agents in response to the impact of current and emerging technologies, in order to create cost-effective tax growth. [5]. Loebbecke and Picot [10] use the term "digitalisation" to refer to the changes in established patterns caused by digital transformation and complementary economic and social innovations. Digitalisation penetrates all areas of life and creates new ways to work, communicate and to work together. Digitalisation enables tax authorities to inculcate an open, agile, knowledge-based and skill-based economy, improve the efficiency and effectiveness of tax administration, and provide taxpayers with advantages through emerging technologies [11].

According to Parviainen et al., [12], digitalisation, as pointed out, already has an impact on business environments and the way a company operates. Digitalisation can affect the entire operating environment and internal functioning of a company. Thus, the impact of digitalisation and the organisation's goals in digitalisation can be identified from three different points of view:

i. Internal efficiency; i.e. better way of working by digital means and internal system replanning;

ii. External opportunities, i.e. new business opportunities (new services, new customers, etc.) in the existing business domain;

iii. Disruptive changes; digitalisation completely causes changes in business roles. [12]

In particular, in order to define the user's readiness for digitalisation, Tsou et al., [13] characterized digital resources as a collection of IT enabled tools in the form of digitised business work processes and information systems through reaching and improving their awareness of digitalisation and using digitalisation in all processes within the organization. Through their interim report, the OECD [14] stated that digitalisation has already had a triple positive impact on tax administration which is enhancing tax compliance efficiency, improving taxpayer services, and reducing tax compliance burdens.

\subsection{Perceived usefulness}

Perceived usefulness is the degree to which users believe that the benefit they would obtain from using new technology would improve their performance in their work [15]. Therefore, a system that is high in perceived usefulness in the context of the adoption of the information system is the belief that it would bring positive results from its use. Some studies 
have shown that perceived usefulness directly affects the readiness to adopt new technology, including theprocess of digitalisation. Consequently, many users find that if the system is useful to them, they will adopt the system and use the system.

\subsection{Perceived ease of use}

Perceived ease of use refers to users who believe that technology would ease their physical and mental effort to when performing their job [15]. This attribute is one of the major behavioral beliefs that influence the intention of users to adopt information technology in conventional or other modified Technology Acceptance Models. In their research, Lu et al. [16] indicated that perceived ease of use has two ways to influence behavioral intention. First, direct effect and second, an indirectly perceived usefulness.

\subsection{Technology infrastructure}

Technology infrastructure is seen as uncomplicated and as something one can or must use in modern society. The utilization of and interaction with digital devices and software are done without an awareness of the influence of the digital technologies [17]. The ignorant mode to technology infrastructure in the digital world highlights various irritations and frustrations that digitally can present in daily lives. Becoming aware of the influence and impact of digital technologies and digitalisation could bring about more democratic directions for digitalism [18]. Technology infrastructure is not limited to technical support, as it also includes the allocation of adequate and appropriate human resource capacity in the operation and management of the built system [19].

\subsection{Compliance cost}

Compliance cost is defined by Sandford et al., [20] as those costs incurred by taxpayers or third parties, such as businesses, in complying with the requirements laid down in respect of a particular tax structure. Compliance costs are expected to increase significantly when a new system or program is introduced. The cost of compliance may depend on a number of different factors, primarily due to tax laws and frequent changes in taxes [21]. The costs of tax compliance are divided into economic and non-economic costs, as defined by Ariff and Pope [22]. The economic costs are listed as monetary and time costs, and non-economic costs is stress and anxiety induced by tax adherence (psychological costs).

\subsection{Government support and policy}

Governments are accountable to the general public for effective and efficient governance as well as precise policy execution and provision of specific public services as approved by parliament to entitled communities [23]. In order to promote digital innovations and encourage the development of these innovations to benefit society, governments and regulatory authorities have to play a significant role. To promote widespread public and consumer interest, governments and regulatory authorities have to provide general rules that represent societal values and desires and restrict potential negative consequences of such developments. Nevertheless, there is often a lack of flexibility in regulatory frameworks when responding to growing technological trends [24]. Acceptance of policy changes and support from the government is crucial as it is the government's essential role). Government 
support is needed to foster better development to prepare the new generation of youth for the future [25].

\subsection{Technology Acceptance Model (TAM) Theory}

Organisations are adopting new innovations to improve the efficiency and effectiveness of various work processes. Unfortunately, many products and services based on technology did not reach their full potential and some were simply rejected [26]. Failed technology investments not only caused financial losses, but also led to employee dissatisfaction [27]. It is therefore important to predict the readiness towards the adoption of new technology or system prior to implementation.

According to Esen \& Erdoğmuş [28], determinants of the use of technology have been studied to predict and explain end-user adoption and acceptance of technology and systems. One of the theories in this area is the traditional Theory of Reasoned Action (TRA) by Fishbein and Ajzen, which describes the attitude of users towards technology in organisations. TRA claims that the action of an individual is determined by his or her intention to act. Therefore, the Technology Acceptance Model (TAM) which was adapted from the TRA is the current prevailing model in this field.

In 1985, Fred Davis created TAM to define the purpose of using and accepting new technology or system in organisations. The TAM theory has two primary factors affecting the willingness of an individual to use new technology: perceived ease of use and perceived usefulness. According to current literature, TAM is a highly cited framework. Chuttur [29] argues that TAM's broad acceptance is based on a sound theoretical assumption and its practical effectiveness. The model was designed to show how users accept and use the technology parallel to the next stage of digitalisation in the Malaysian taxation administration.

As stated by Davis, the model in Figure 1 explains the relationship between these determinants.

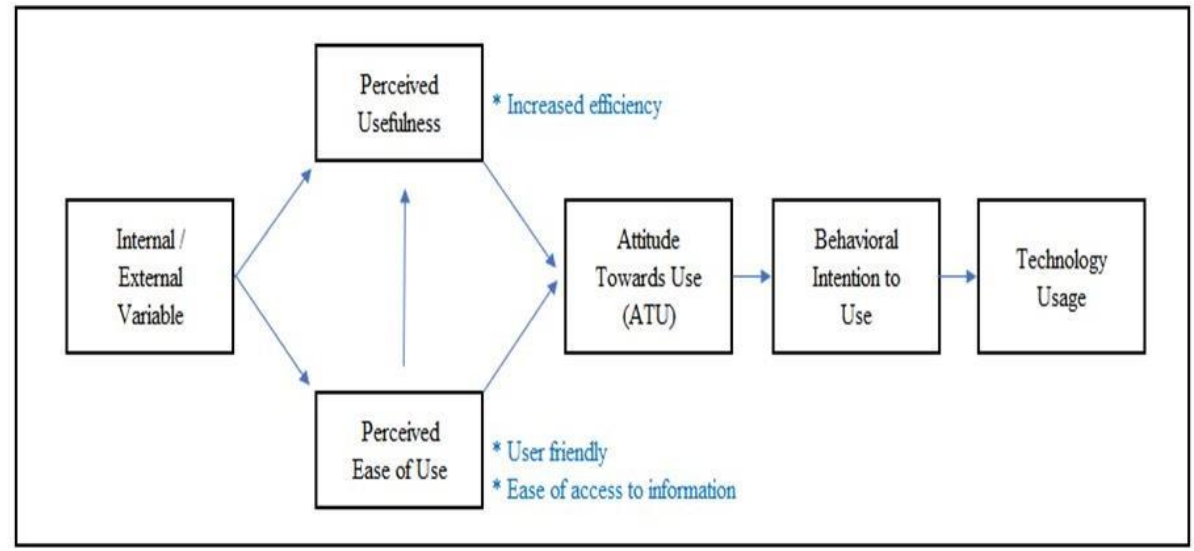

Fig. 1. The framework of Technology Acceptance Model Theory Source: Davis, 1989 The theoretical basis is based on the premise that three significant factors affect 
decision making, how and when users would use it when faced with new technology. The first determinant is perceived usefulness (PU) and the second is perceived ease of use (PEOU), while the third determinant is the attitude towards usage (ATU). According to Davis [15], perceived usefulness is the degree to which a user assumes that using a specific system will improve the performance of his or her work. On the other hand, perceived ease of use is the degree to which a user believes that it would be effortless to use a particular technology. In other words, the degree to which users consider technology to be greater than its substitutes.

Future digitalisation users including tax agents may not base their acceptance and willingness to use new technology on their understanding of the utility of IT and how simple it is to use it as the model suggests that there may be other external factors that may be responsible for their acceptance of the technology [30]. As a result of several studies and replications, TAM is the widely accepted study of technology acceptance and has been implemented in different contexts by multiple researchers on different applications of technology [31]

The main advantages of TAM are its flexibility, adaptability and logical soundness, making it the most widely recognised model at the moment [32]. Therefore, Chong et al. [33] suggest that the TAM should be used as a basic model for assessing user acceptance for digitalisation, with a focus on identifying determinants that might impact tax agents' readiness to shift to the next phase of digitalisation.

\section{Research Framework}

The first two independent variables are perceived usefulness and perceived ease of use whereby these two perceptual beliefs are presented as the key determinants in the adoption of new technologies including digitalisation based on the Technology Acceptance Model theory. In addition, other independent variables are technology infrastructure, compliance costs, government policy and government support [34].

The framework of this study is formed based on the research conducted by Ernst \& Young [35], KPMG [36] and OECD [37] which discussed the digitalisation of the tax administration across the globe, and the report from Asia Development Bank [38] on the risk and success of digitalisation together with the tax agents roles related to the implementation of the digitalisation strategies. Figure 2 depicts the research framework for all the five hypotheses. 


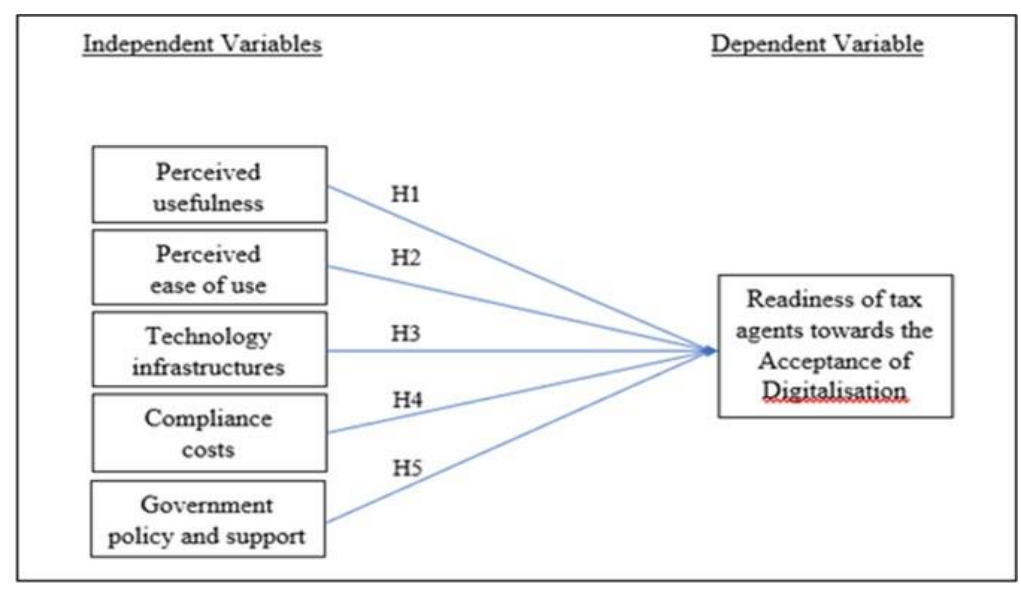

Fig. 2. Research Framework of Study

Based on the research theme, the hypotheses in this study are developed and transformed into variables as portrayed in the research framework. Therefore, the following hypotheses are developed:

H1: There is a positive relationship between perceived usefulness and the readiness of tax agents on the digitalisation of tax administration.

$\mathrm{H} 2$ : There is a positive relationship between perceived ease of use and the readiness of tax agents on the digitalisation of tax administration.

H3: There is a positive relationship between technology infrastructure and the readiness of tax agents on the digitalisation of tax administration.

H4: There is a positive relationship between the compliance costs and the readiness of tax agents on the digitalisation of tax administration.

H5: There is a positive relationship between the government policy and support and the readiness of tax agents on the digitalisation of tax administration.

\section{Research Method}

This study is cross-sectional as the questionnaires are distributed to tax agents in Malaysia. The questionnaire was prepared in English and the Malay language. For study's sampling frame, the list of tax agents was obtained from the Inland Revenue Board Malaysia (IRBM)'s website.

\section{Data analysis}

The questionnaires were distributed through email and WhatsApp application to tax 
agents throughout Malaysia. Within a month, 173 questionnaires were returned. Tax agents were selected because they have more experience as intermediaries between tax authorities and taxpayers. Tax agents are frequently in charge of various transactions in the IRBM tax system, from the issues of individual taxpayers to the transactions of corporate taxpayers, using all of the online services provided by the IRBM. A total of 173 questionnaires were used for further analysis.

\section{Findings}

\subsection{Demographic Profile}

This section explains the demographic profile analysis for all the respondents who took part in this study. The analysis presents the results in terms of gender, age and the working experiences of the respondents.

\subsection{Gender}

From this study, the distribution of survey to female tax agents has been found to be higher than male. The percentage of female tax agents is 7.6 percent higher than their male counterpart. This indicates that more female respondents participated in answering the distributed questionnaires. Table 2 shows the distribution of the respondents' gender.

Table 2. Result of Respondents' Gender

\begin{tabular}{lll}
\hline Gender & Frequency & Percentage $(\%)$ \\
\hline Female & 93 & 53.8 \\
Male & 80 & 46.2 \\
\hline Total & 173 & 100.0 \\
\hline
\end{tabular}

\subsection{Age}

Most of the respondents are under the age of 31, which constitutes 41.6 percent of the total sample. The smallest percentage, is 8.7 percent, representing those who are over 51 years old. As the distribution of questionnaire is done by email blast and WhatsApp application, it is not unusual to attract the younger tax agents who are more tech-savvy. Table 3 illustrates the result of the respondents' age.

Table 3. Result of Respondents' Age

\begin{tabular}{lll}
\hline Age & Frequency & Percentage $(\%)$ \\
\hline Less than 31 & 72 & 41.6 \\
31 to 40 years old & 47 & 27.5 \\
41 to 50 years old & 39 & 22.5 \\
51 and above & 15 & 8.7 \\
\hline Total & 173 & 100.0 \\
\hline
\end{tabular}




\subsection{Length of Service}

Table 4 shows that 33.5 percent of the tax agents have a length of service less than 5 years, followed by those who are in service between 5 to 10 years (23.7 percent). Those who are in service for 15 years and above constitute 22.5 percent. The rest reported to have been in service between 11 to 15 years (20.2 percent).

Table 4. Length of Tax Agent Service ( $n=173)$

\begin{tabular}{lll}
\hline Number of years & Frequency & Percentage (\%) \\
\hline Less than 5 years & 58 & 33.5 \\
5 to 10 years & 41 & 23.7 \\
11 to 15 years & 35 & 20.2 \\
More than 15 years & 39 & 22.5 \\
\hline Total & 173 & 100.0 \\
\hline
\end{tabular}

\subsection{Relationship between Tax Agents' Readiness towards Digitalisation and Factors Contributing to Readiness}

Table 5. Correlation Analysis between Tax Agents' Readiness towards Digitalisation and Factors Contributing to Readiness

\begin{tabular}{lcc}
\hline \multirow{2}{*}{ Variables } & \multicolumn{2}{c}{ Tax agents' readiness towards digitalisation } \\
\cline { 2 - 3 } Perceived Usefulness & 0.336 & $p$-value \\
Perceived Ease of Use & 0.568 & $0.000^{* *}$ \\
Technology Information & 0.599 & $0.000^{* *}$ \\
Compliance Cost & 0.568 & $0.000^{* *}$ \\
Government Policy and support & 0.586 & $0.000^{* *}$ \\
\hline
\end{tabular}

** Significant at 0.01

Source: IBM SPSS software package

Table 5 shows that tax agents' readiness towards digitalisation is positively and moderately correlated with technology infrastructure $(\mathrm{r}=0.599 ; \mathrm{p}<0.01)$, government policy and support ( $\mathrm{r}$ $=0.586 ; \mathrm{p}<0.01)$, perceived ease of use $(\mathrm{r}=0.568 ; \mathrm{p}<0.01)$, and compliance cost $(\mathrm{r}=0.568$; $\mathrm{p}<0.01)$. Therefore, an increase of tax agents' readiness towards digitalisation is associated with an increase in technology infrastructure, government policy and support, perceived ease of use, compliance cost and vice versa.

However, it also shows that tax agents' readiness towards digitalisation is positively but lowly correlated with perceived usefulness $(\mathrm{r}=0.336$; $\mathrm{p}<0.01)$. That is, to a small extent, an increase of tax agents' readiness towards digitalisation increases perceived usefulness, and vice versa. Factors Affecting Tax Agents' Readiness 
Table 6 provides a statistical overview of the approximate regression equation.

Table 6. Estimated Regression Equation

\begin{tabular}{llll}
\hline Variable & Coefficient & $t$-value & $p$-value \\
\hline Perceived Usefulness & -0.144 & -1.783 & 0.076 \\
Perceived Ease of Use & 0.198 & 2.007 & $0.046^{*}$ \\
Technology Information & 0.221 & 2.509 & $0.013^{*}$ \\
Compliance Cost & 0.244 & 3.467 & $0.001^{* *}$ \\
Government policy and support & 0.265 & 3.431 & $0.001^{* *}$ \\
\hline $\mathrm{F}$ & 27.748 & & $0.000^{* *}$ \\
\hline $\mathrm{R}^{2}$ & 0.457 & & \\
\hline$*$ Significant at 0.05 & & & \\
** Significant at 0.01 & & & \\
Source: IBM SPSS software package & & &
\end{tabular}

The regression equation is statistically significant at $0.01(\mathrm{p}<0.01)$, implying that there is a relationship between tax agents' readiness towards digitalisation and all of the independent variables. The r-square value at 0.457 means that the five independent variables as a whole account for 46 percent of the variation in the dependent variable (tax agents' readiness to digitalisation). Hence, the effect of perceived usefulness, perceived ease of use, technology infrastructure, compliance cost and government policy and support as a whole on tax agents' readiness towards digitalisation is moderate.

Looking at the individual regression coefficient, one finds that only the coefficient of perceived ease of use, technology infrastructure, compliance cost and government policy and support are statistically significant at $0.05(\mathrm{p}<0.05)$ and $0.01(\mathrm{p}<0.01)$ respectively. Only perceived usefulness is not significant.

The coefficients of perceived ease of use (0.198), technology infrastructure $(0.221)$, and compliance cost $(0.224)$ and government policy and support $(0.265)$ means that an increase in these variables increases the tax agents' readiness towards digitalisation, whilst changes in perceived usefulness have no impact on tax agents' readiness. The linear regression equation for this study is derived from the coefficient result. Table 7 reports the coefficient results.

Table 7. Coefficient Result

\begin{tabular}{lcc}
\hline Unstandardised Coefficients & B & Std. Error \\
\hline (Constant) & .738 & .294 \\
Perceived Usefulness & -.137 & .077 \\
Perceived Ease of Use & .181 & .090 \\
Technology Information & .212 & .084 \\
Compliance Cost & .251 & .072 \\
\hline Government policy and support & .258 & .075 \\
\hline
\end{tabular}

Source: IBM SPSS software package 
As shown in Table 7 above the regression equation can be developed to answer the research questions. The multiple regression equation is derived as follows:

$$
\begin{aligned}
& \mathrm{Y}=\beta 0+\beta 1 \mathrm{PU}+\beta 2 \mathrm{PEOU}+\beta 3 \mathrm{TI}+\beta 4 \mathrm{CC}+\beta 5 \mathrm{GPAS}+\varepsilon \\
& \mathrm{Y}=.738-.137 \mathrm{PU}+.181 \mathrm{PEOU}+.212 \mathrm{TI}+.251 \mathrm{CC}+.258 \mathrm{GPAS}+\varepsilon
\end{aligned}
$$

Where;

$\begin{array}{lll}\mathrm{Y} & = & \text { Tax agents' readiness towards Digitalisation } \\ \beta 0 & = & \text { Constant value } \\ \beta & = & \text { Regression coefficient } \\ \text { PU } & = & \text { Perceived usefulness } \\ \text { PEOU } & = & \text { Perceived ease of use } \\ \text { TI } & = & \text { Technology infrastructure } \\ \text { CC } & = & \text { Compliance costs } \\ \text { GPAS } & = & \text { Government policy and support } \\ \varepsilon & = & \text { Residual term (error) }\end{array}$

\section{Conclusion}

The results of this study revealed that tax agents are ready to accept digitalisation if it is to facilitate taxation in the era of Industry 4.0. Digitalisation is seen as advantageous to tax agents when the tax authority replaces the conventional tax administration model with a new model that analyses and uses a large amount of information available on the internet and systemic resources [39]. They explore the benefit of opportunities offered by digitalisation and use it to automate processes, reduce costs, increase efficiency, remain competitive or drive innovation and new business models [40]. Most of them will give priority to digitalisation in tax administration, but they will expect the highest added. This is supported by a study conducted by ICAEW [6] which looks at the whole story of digitalisation, from taxation targets to the specific tools used to manage tax administration and takes into account the needs and desires of various stakeholders in the tax system.

The research also explores how each determinant influences digitalisation in order to move from current methods to the new upgraded digital taxation tools. In addition, while the respondents acknowledged that they are ready for digitalisation, they also admitted that adopting the updated digital environment is too difficult to be useful. It may be concluded that most of them are willing to learn and participate in the digitalisation of tax administration and they need time to get used of it.

As the tax authority, the IRBM, according to this study would be the one who benefits the most. As previous studies focused on e-filing, tax compliance, and other tax issues, only a few paid attentions to the digitalisation of tax administration, especially when it comes to readiness that involves tax agents who are the intermediaries between the tax authority and taxpayers. Identifying factors that will affect tax agents' readiness may assist the IRBM to realize that there are several gaps in the system that other studies have not uncovered. The information provided in this study may be used by the IRBM to decide which factors contribute most to the process of 
digitalisation. This is crucial in order to avoid any unnecessary government investments to upgrade tax administration.

This study provides a platform for tax agents or tax practitioners to response to the digitalisation of tax administration and voice their concerns about the new system. The consideration of tax agents' readiness is important when delivering the best services to their clients. Moreover, digitalisation can enhance their workflow and may contribute to assisting and supporting their clients' tax compliance. Improving tax compliance of taxpayers would lead to a reduction in the tax gap and increase government revenue. Therefore, with the digitalisation of tax administration in Malaysia, tax agents can act professionally on behalf of their client in compliance with the set deadline as well as with the rules and regulations without any error.

Further research in this field of study is highly recommended. Since the era of Industry 4.0 , the digitalisation process of tax administration in Malaysia will be one of valuable contribution to academicians, practitioners, government and related agencies. Thus, future researchers can widen the sample to better understand tax agents' readiness and acceptance of digitalisation.

The findings of the current study could be more valuable to practitioners to recognize factors that can help improve taxation matters. As for the theoretical part, researchers can choose from the identified factors to guide them to identify potential factors that would help the process of digitalisation to move to the next level. From this study, researchers can extend the tax field by looking at the technological aspects and explore them in deeper context. Overall, this study is helpful in the sense that it allows practitioners and academicians to have a better insight and understanding about the digitalisation of tax administration in Malaysia.

\section{References}

[1] K. L. R. B. F. P. Williem P. D. G., "Impact of digitalisation and the on-demand economy on labour markets and the consequences for employment and industrial relations," European Economic and Social Committee, p. 2, 2017.

[2] H. J. L. O. \&. O. Fransson G., "Digitalise and capitalise? Teachers' self-understanding in 21stcentury teaching contexts," Oxford Review of Education, p. 11, 2018.

[3] M. Vuković, "Towards the Digitization of Tax Administration," Centre of Excellence of Finance, $30 \mathrm{Jul} 2018$.

[4] K. M. Y. S. H. \&. M. R. Isa, " The Role of Tax Agents in Sustaining the Malaysian Tax System," Procedia - Social and Behavioral Sciences, , no. 164, pp. 366-371, 2014.

[5] E. a. Young, "Tax technology and transformation - Tax functions 'go digital'," Ernst and Young, 2017. [Online]. Available: https://assets.ey.com/content/dam/ey-sites/eycom/en_gl/topics/digital/ey-tax-technology-transformation.pdf.

[6] ICAEW, "Digitalisation of tax: International perspectives," ICAEW, 2019. [Online]. Available: https://www.icaew.com/-/media/corporate/files/technical/information-technology/techfaculty/digital-tax.ashx.

[7] B. Power, "Acuity Magazine," 2016. [Online]. Available: https://www.acuitymag.com/finance/therole-of-accountants-in-a-digitalisedtax-system.

[8] ICAEW, "Digitalisation of tax: international perspectives," CAEW Thought Leadership, IT Faculty,2019 Edition, 2019. 
[9] Deloitte, "Deloitte Digital business obstacle: Digitisation - How can I make the most of my organization's digital transformation?," Deloitte Insights, 2018. [Online]. Available: https://www2.deloitte.com/lu/en/pages/technology/articles/deloitte-digital-business- obstacleorganization-digitization.html .

[10] C. a. P. A. Loebbecke, "Reflections on societal and business model transformation arising from digitisation and big data analytics: A research agenda," Journal of Strategic Information Systems, vol. 24, pp. 149-157, 2015.

[11] OECD, "Tax and digitalisation, OECD Going Digital Policy Note," OECD, Paris, 2018. [Online]. Available: http://www.oecd.org/going-digital/topics/tax.

[12] P. T. M. K. J. a. T. S. Parviainen, "Tackling the digitalisation challenge: How to benefit from digitalisation in practice," International Journal of Information Systems and Project Management, vol. 5, pp. 63-77, 2017.

[13] H.-T. a. H. S. H.-Y. Tsou, "Performance effects of technology-organisation- environment openness, service co-production, and digital-resource readiness: The case of the fIT industry," International Journal of Information Management, vol. 35(1), pp. 1-14, 2015.

[14] OECD, "Tax Challenges Arising from Digitalisation - Interim Report 2018," OECD, 2018. [Online]. Available: https://www.oecd.org/ctp/tax-challenges-arising-from-digitalisation-interim-report9789264293083-en.htm.

[15] F. Davis, "Perceived Usefulness, Perceived Ease of Use, and User Acceptance of Information Technology," MIS Quarterly,, vol. 13, pp. 319-340, 1989.

[16] J. \&. Y. J. \&. Y. C.-S. Lu, "Personal Innovativeness, Social Influences and Adoption of Wireless Internet Services via Mobile Technology," The Journal of Strategic Information Systems, vol. 14, pp. 245-268, 2005.

[17] T. \&. D. M. Dufva, "2019," Grasping the future of the digital society, vol. 107, pp. 17-28, 2019.

[18] J. R. L. Anderson, "The Future Of Well-Being in A Tech-Saturated World, Concerns About The Future Of People's Well-Being," Pew Research Centre, 2018. [Online]. Available: https://www.pewresearch.org/internet/2018/04/17/concerns-about-the-future-of- peoples-wellbeing/.

[19] P. S. M. a. B. M. Weill, "Building IT Infrastructure for Strategic Agility," MIT Sloan Management Review, pp. 57-66, 2003.

[20] C. G. M. H. P. Sandford, "Administrative and Compliance Costs of Taxation.," Fiscal publications, Bath., 1989.

[21] M. R. R. R. M. A. F. a. H. N. S. A. Palil, "Elements of Compliance Costs: Lesson from Malaysian Companies towards Goods and Services Tax (GST)," Asian Social Science, p. 9(11), 2013.

[22] M. \&. P. J. Ariff, "Taxation and compliance costs in Asia Pacific economies," Sintok: Universiti Utara Malaysia., 2002.

[23] S. M. F. \&. M. K. A. A. Kiow, "The Determinants of Individual Taxpayers' Tax Compliance Behaviour in Peninsular Malaysia," International Business and Accounting Research Journal, vol. Vol. 1. 10.15294/ibarj.v1i1.4, 2017.

[24] OECD, "Regulatory effectiveness in the era of digitalisation," OECD, 2019. [Online]. Available: https://www.oecd.org/gov/regulatory-policy/Regulatory-effectiveness-in-the-era-ofdigitalisation.pdf.

[25] OECD, "Tax Challenges of Digitalisation," OECD, 2017. [Online]. Available: https://www.oecd.org/tax/beps/tax-challenges-digitalisation-part-2-comments-on-request-forinput-2017.pdf.

[26] A. \&. H. G. S. Burton-Jones, "The mediation of external variables in the technology acceptance model," Information \& Management, vol. 43, pp. 706-717, 2006.

[27] V. Venkatesh, "Determinants of perceived ease of use: Integrating control, intrinsic motivation, and 
emotion into the technology acceptance model," Information Systems Research, vol. 11, pp. 342$365,2000$.

[28] M. \&. E. N. Esen, "Effects of Technology Readiness On Technology Acceptance In E-HRM: Mediating Role Of Perceived Usefulness," in 7th International Strategic Management Conference, Paris, France, 2014.

[29] M. Chuttur, "Overview of the Technology Acceptance Model: Origins, Developments and Future Directions," Working Papers on Information Systems., vol. 9, 2009.

[30] B. L. E. G. K. a. I. Tabrizi, "Digital Transformation Is Not About Technology," Harvard Business Review, 2019. [Online]. Available: https://hbr.org/2019/03/digital- transformation-is-not-abouttechnology.

[31] S. a. P. A. Rathore, "Factors Influencing Behavioural Intention to use Smart Phones," Global Vistas, pp. 19-28, 2015.

[32] S. S. P. J. C. a. G.-P. F. J. Olmos M., "Behavioral Intention of Use of Mobile Technologies Among Pre-Service Teachers. Implementation of a technology adoption model based on TAM with the constructs of Compatibility and Resistance to Change," 2015 International Symposium on Computers in Education (SIIE), pp. 120-125, 2015.

[33] A. Y. L. C. F. T. a. O. K. B. Chong, "Predicting consumer decisions to adopt mobile commerce: Cross country empirical examination between China and Malaysia," Decision Support Systems, vol. 53(1), pp. 34-43, 2012.

[34] S. \&. B. S. Sternad, " Impacts of TAM-based External Factors on ERP Acceptance," Procedia Technology, pp. 9, 33-42, 2013.

[35] E. a. Young, "EY Global," EY, 2019. [Online]. Available: https://www.ey.com/en_gl/tax/how-taxadministration-is-going-digital.

[36] KPMG, "Digitalization of tax," KPMG, 2019. [Online]. Available: https://home.kpmg/xx/en/home/insights/2019/08/digitization-in-tax.html.

[37] OECD, "Tax and digitalisation," OECD, March 2019. [Online]. Available: https://www.oecd.org/going-digital/tax-and-digitalisation.pdf.

[38] A. D. Bank, "The Digital Revolution in Asia and Its Macroeconomic Effects," ADB Institute, October 2019. [Online]. Available: https://www.adb.org/publications/digital-revolution-asiamacroeconomic-effects.

[39] OECD, "Tax Challenges of Digitalisation - Comments Received on the Request for Input - Part II," OECDtax, 25 October 2017. [Online]. Available: https://www.oecd.org/tax/beps/tax-challengesdigitalisation-part-2-comments-on-request-for-input-2017.pdf.

[40] M. R. R. M. C. V. W. a. S. E. Rachinger, "Digitalisation and its influence on business model innovation," Journal of Manufacturing Technology Management, vol. 30, no. 8, pp. 1143-1160, 2019. 